\title{
掲載論文の撤回のお知らせ
}

真田 樹義, 宮地 元彦, 山元 健太, 村上 晴香, 谷本 道哉, 大森 由実, 河野 寛, 丸藤 祐子, 塙 智史, 家光 素行, 田畑 泉, 樋口 満, 奥村 重年

日本人成人男女を対象としたサルコペニア簡易評価法の開発

体力科学 第59巻 第3号 291-302 (2010) DOI : 10.7600/jspfsm.59.291

\section{理 由}

体力科学 第59巻 第 3号 291-302（2010）掲載論文における身体組成データ収集の過程で, 資格を持たない者がX線骨密度測定装置を操作したことを理由とした著者からの掲載論文撤回 の希望を受け，本誌より撤回する。

一般社団法人日本体力医学会 編集委員長 田中 喜代次 